\section{A Modification}

\section{of the Slanting} Deer Fence

\section{HAROLD E. MESSNER, DONALD R. DIETZ, AND E. CHESTER GARRETT}

Highlight: A slanting deer fence is designed that requires less mesh wire and shorter posts than the standard upright deer fence. The slant ing fence blends well into forest and meadow backgrounds and will withstand greater snow loads than existing slanting deer fences.

Fencing has been used sparingly to control deer use or damage on large areas of land largely because of the high cost of construction and maintenance. We needed to exclude deer and livestock from three 1/3-acre plots being used for tests of imported grass and legume seeds. A fence economical to build, pleasing to the eye, and blending into the surrounding scenery of ponderosa pine was desired.

The standard deer fence described by Halls et al. (1965) and Bartlett and Boyce (1954) was both expensive and rather unsightly because of its height. The "outrigger" type deer fence discussed by Blaisdell and Hubbard (1956) was also deemed too expensive and somewhat unsightly. The "outrigger" fence is essentially a 4.5-ft upright fence with an outrigger sloping outward from the top to a point on the ground $8 \mathrm{ft}$ from the base. The "outrigger" prevents the deer from getting close enough to jump the fence.

A modification of the overhanging or slanting type deer fence proposed by Longhurst et al. (1962) and Jones and Longhurst (1958) appeared to best fit our needs.

The authors are range technician, principal wildlife biologist, and range technician, respectively, Rocky Mountain Forest and Range Experiment Station, Forest Service, U. S. De partment of Agriculture. Research reported here was conducted at Rapid City, in cooperation with South Dakota School of Mines and Technology. Station's central headquarters is maintained at Fort Collins, in cooperation with Colorado State University.

Manuscript received December 27, 1972.

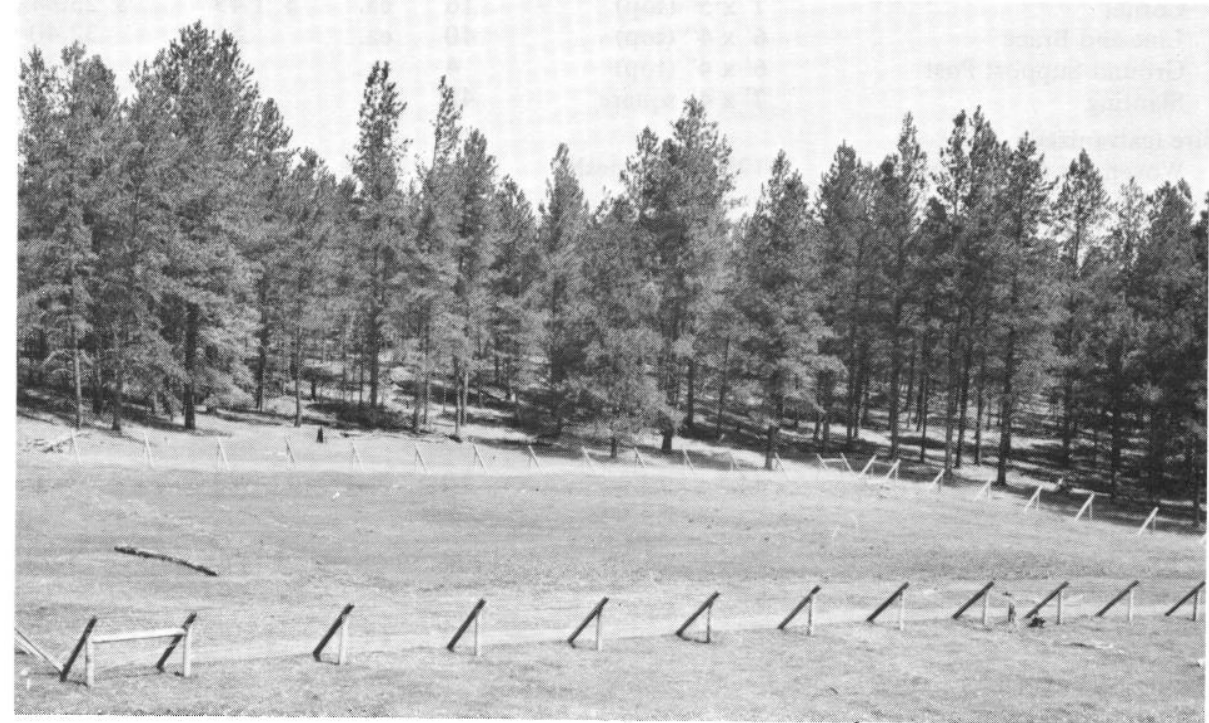

Fig. 1. Slanting deer fence successfully excluded white-tailed deer from experimental plots in the Black Hills of South Dakota.

\section{Materials and Design}

The slanting fence designed by Longhurst et al. (1962) consisted of mesh wire supported between two guy wires. The main disadvantage to this design is that, in areas of heavy snowfall, the slanting fence is apt to be crushed by the weight of snow.

Our design included a 7-ft (4-inchsquare) sloping post fastened to each vertical line post for additional support against heavy snowfall (Fig. 1). The slant of the fence was achieved by cutting the top of the vertical posts at a $45^{\circ}$ angle at $4 \mathrm{ft}$ above ground level and attaching a square 7 -ft post with an 8 -inch spike. The 1 -ft overhang was provided by the extension of the top of the slanting post past the vertical post. The bottom of the sloping post rested on the ground $4.5 \mathrm{ft}$ from the line post, forming an angle of about $45^{\circ}$. The 6 -foot line posts were set in 2-ft holes spaced $12 \mathrm{ft}$ apart.

Corners for the slanting fence were constructed by setting in the ground two 7 -ft vertical posts 30 inches deep and $6 \mathrm{ft}$ apart. These were braced with a 6 -ft line post placed horizontally about $3 \mathrm{ft}$ above ground level. The sloping posts at the corners were secured at ground level with an 8-inch spike to an 18-inch section of a 4-inch-diameter post set approximately 12 inches deep. Both 7-ft and 18-inch vertical corner posts were notched at the top with a $45^{\circ}$ cut (Fig. 2) to receive the sloping posts and hold them against horizontal stress.

Starting at ground level and working up, the following fencing materials (Table 1) were fastened to the upper side of the sloping posts: (1) four strands of barbed wire; (2) one 48-inch-wide woven wire; and (3) two more strands of barbed wire. Small mammals were discouraged from entering between the lower barbed wire strands by a 24-inch wire mesh (fastened with hog rings) laid across the barbed wire between ground level and the woven wire. A pie-shaped wedge of woven wire and several strands of barbed wire were used to close the opening at each fence corner (Fig. 1).

The material and labor for the overhanging fences were furnished by the Boxelder Job Corps at Nemo, S. Dak. The number of man-hours required to build the exclosures was not determined since the training nature of the construction made an accurate accounting of time impossible.

\section{Results and Discussion}

During the past five years, deer, livestock, and some small mammals were successfully excluded by the overhanging fence. 
Longhurst et al. (1962) felt the slanting fence is effective because it acts primarily as a psychological barrier to

Table 1. Specifications and costs of material to enclose a square approximately one-third acre plot $(120 \times 120 \mathrm{ft})$ with the modified slanting deer fence.

\begin{tabular}{|c|c|c|c|c|c|}
\hline Description & Specification & No. & Unit & $\begin{array}{l}\text { Unit } \\
\text { cost }\end{array}$ & Total \\
\hline \multicolumn{6}{|l|}{$\overline{\text { Posts }}$} \\
\hline Corner & $7^{\prime} \times 5^{\prime \prime}$ (top) & 16 & ea. & $\$ 1.49$ & $\$ 23.84$ \\
\hline Line and Brace & $6^{\prime} \times 4^{\prime \prime}$ (top) & 40 & ea. & .81 & 32.40 \\
\hline Ground Support Post & $6^{\prime} \times 4^{\prime \prime}$ (top) & 4 & ea. & .81 & 3.24 \\
\hline Slanting & $7^{\prime} \times 4^{\prime \prime}$ square & 48 & ea. & 1.38 & 66.24 \\
\hline \multicolumn{6}{|l|}{ Wire (galvanized) } \\
\hline Woven for main course & $\begin{array}{l}12^{1 / 2} \text { gauge mesh, } \\
\text { horizontal strands, } \\
10 \text { gauge, } 48^{\prime \prime} \text { wide, } \\
20 \text { rods long }\end{array}$ & 1.5 & rolls & 25.75 & 38.63 \\
\hline $\begin{array}{l}\text { Barbed, for fence top, } \\
\text { bottom and bracing }\end{array}$ & $\begin{array}{l}12^{1 / 2} \text { gauge, } 2 \text { pt., } \\
80 \text { rods long }\end{array}$ & 2.3 & rolls & 8.75 & 20.13 \\
\hline $\begin{array}{l}\text { Wire mesh at fence } \\
\text { bottom to exclude } \\
\text { small animals }\end{array}$ & $\begin{array}{l}150^{\prime} \times 24^{\prime} \text { with } 1^{\prime \prime} \\
\text { hexagon openings }\end{array}$ & 3.2 & rolls & 8.85 & 28.32 \\
\hline Staples & $13 / 4$ & 10 & lbs. & .23 & 2.30 \\
\hline \multicolumn{6}{|l|}{ Hog Rings } \\
\hline $\begin{array}{l}\text { Join mesh with woven } \\
\text { and barbed wires }\end{array}$ & No. 1 & 1000 & ea. & .005 & 5.00 \\
\hline Nails & $8 "$ spike & 80 & ea. & .09 & 7.20 \\
\hline \multicolumn{5}{|l|}{ Total cost } & $\$ 227.30$ \\
\hline \multicolumn{5}{|l|}{ Cost per rod } & 7.81 \\
\hline \multicolumn{6}{|c|}{ Alternate Plan with Change in Slanting Post Specifications } \\
\hline \multicolumn{6}{|l|}{ Posts } \\
\hline Slanting & $7^{\prime} \times 3^{\prime \prime}$ (top) & 48 & ea. & .60 & 28.80 \\
\hline Other Materials with No Change & & & & & 161.06 \\
\hline Total cost & & & & & $\$ 189.86$ \\
\hline Cost per rod & & & & & 6.52 \\
\hline
\end{tabular}

not try to jump.

Two disadvantages of the overhanging fence are (1) cattle may damage the wire by using it for a backrub, and (2) in areas of rough terrain some land leveling would be required. The first may be overcome by attaching two strands of No. 9 galvanized wire around the outside of the vertical posts at 18 - and 30 -inch heights. This will still permit young calves and deer to utilize the undergrowth beneath the slanting portion of the fence.

The sloping posts prevented our fence from collapsing under heavy accumulations of snow. However, our exclosures were well protected from drifting snow by the surrounding pine forest. In open country the fence would probably be less effective because of drifting and piling snow.

Costs of constructing slanting fences with round posts are generally lower than upright fences (Table 1). Shorter posts are cheaper, although more are needed in the slanting fence compared to the longer posts used in the upright fence. The amount of mesh wire required for the slanting fence is approximately half that needed for the upright fence, although more barbed wire is needed. Six strands (two above and four below) were used, while two are used (bottom and top) on the 8 -ft or higher upright fence. Based on 1972 prices, materials would cost $\$ 6.52$ per rod for the slanting fence compared to $\$ 7.95$ per rod for an upright fence if round posts are used. Square posts for the slant rather than round posts would increase the material costs from $\$ 6.52$ to $\$ 7.81$ per rod. Maintenance costs have been minimal during the three-year study.

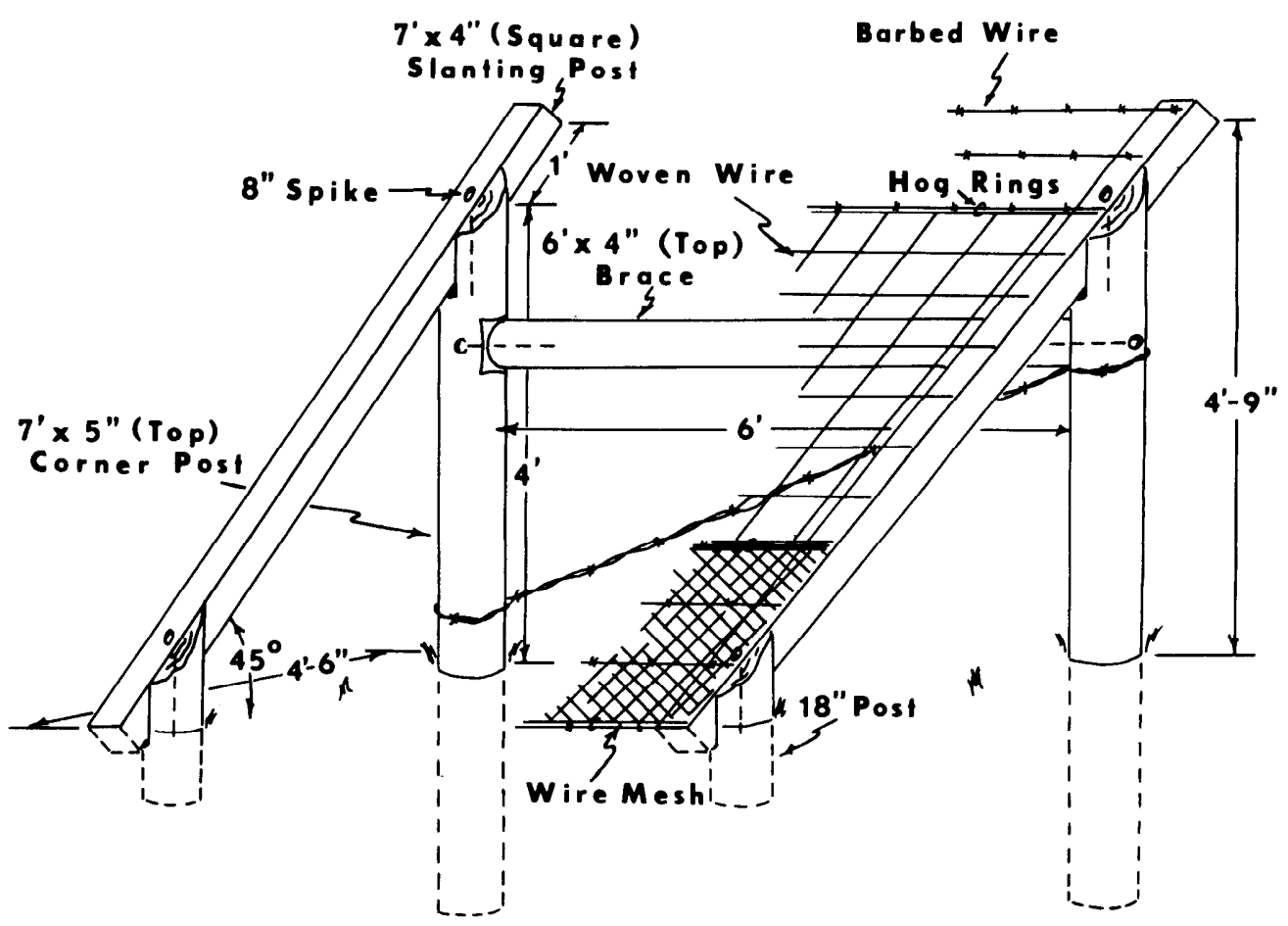

Fig. 2. Diagonal view of slanting deer fence showing construction. 
The slanting type fence should be considered, not only by deer researchers and managers, but also by orchardists, farmers, and ranchers for protecting haystacks, valuable trees, gardens, and small plots.

\section{Literature Cited}

Bartlett, I. H., and A. P. Boyce. 1954. Decr- proof fences. Mich. Dep. of Conserv., Game Div. Rep. 1199, 5 p. (Mimeogr.)

Blaisdell, James A., and Richard L. Hubbard. 1956. An "outrigger" type deer fence. U.S. Dep. Agr., Res. Note 108, Calif. Forest and Range Exp. Sta., 2 p., Berkeley, Calif.

Halls, L. K., C. E. Boyd, D. W. Lay, and P. D. Goodrum. 1965. Deer fence construction and costs. J. Wildlife Manage. 29:885-888. Jones, Milton B., and William M. Longhurst. 1958. Overhanging deer fences. J. Wildlife Manage. 22:325-326.

Longhurst, G. A., M. B. Jones, R. R. Parks, L. W. Neubauer, and M.W. Cummings. 1962. Fences for controlling deer damage. Calif. Agr. Exp. Sta. Ext. Serv. Circ. 514. 15 p. 